\title{
Deletion Mapping of H-Y Antigen to the Long Arm of the Human Y Chromosome
}

\author{
Michael A. Cantrell, ${ }^{*}$ Jonathan S. Bogan, † Elizabeth Simpson, $\ddagger$ James N. Bicknell, ${ }^{*}$ Els Goulmy, $\$$ \\ Phillip Chandler, $\ddagger$ Roberta A. Pagon," David C. Walker, ${ }^{\star}, !$ Horace C. ThUline, II \\ John M. Graham, JR., ${ }^{* *}$ Albert de la Chapelle, †† David C. PAge, † and Christine M. Disteche ${ }^{*}$
}

\begin{abstract}
*Department of Pathology, University of Washington, Seattle, Washington 98195, †Howard Hughes Research Laboratories at Whitehead Institute, and Department of Biology, Massachusetts Institute of Technology, Cambridge, Massachusetts 02142, $\neq$ Transplantation Biology Section, Clinical Research Center, Watford Road, Harrow, Middlesex HA1 3U1, United Kingdom, §Department of Immunohaematology and Blood Bank, AZL, University Hospital, 2300 RC Leiden. The Netherlands, "Department of Pediatrics and Medicine, University of Washington, Seattle, Washington 98195, TGenetics Service Section, State of Washington, Department of Social and Health Sciences, Seattle, Washington 98155, ** Ahmanson Pediatric Center, Medical Genetics Birth Defects Center, Cedar-Sinai Medical Center, University of California, Los Angeles, California 90048, and ††Department of
\end{abstract} Medical Genetics, University of Helsinkı, 00290 Helsinkı 29, Finland

Recelved April 1, 1992, revised May 19, 1992

A gene encoding or controlling the expression of the $H-Y$ transplantation antigen was previously mapped to the human $Y$ chromosome. We now report the sublocalization of this gene on the long arm of the human $Y$ chromosome. Eight patients with $Y$-chromosomal abnormalities were examined with a series of existing and new DNA markers for the $Y$ chromosome. The resulting deletion map was correlated with $\mathrm{H}-\mathrm{Y}$ antigen expression. We conclude that the $H-Y$ antigen gene maps to a portion of deletion interval 6 that is identified by specific DNA markers. (c) 1992 Academı Press, Inc.

\section{INTRODUCTION}

The H-Y transplantation antigen was first discovered by transplanting syngeneic male tissue into female mice (Eichwald and Silmser, 1955). Subsequently, H-Y antigen-specific $\mathrm{T}$-cell responses were generated in vitro from mice (Gordon et al., 1975) and humans (Goulmy et al., 1977; reviewed in Simpson, 1982). A gene encoding or controlling the expression of the $H-Y$ antigen was mapped to the human $\mathrm{Y}$ chromosome by the analysis of sex-reversed patients. Sex-reversed 46, XX males, who carry a portion of the short arm of the $\mathrm{Y}$ chromosome on one of their X chromosomes (Guellaen et al, 1984), are $\mathrm{H}-\mathrm{Y}$ antigen negative, separating the loci for $\mathrm{H}-\mathrm{Y}$ antigen and sex determination (Simpson et al., 1987). In addition, our previous studies have shown that $46, \mathrm{XY}$ sexreversed females with deletions of the short arm of the $Y$ chromosome (Disteche et al,, 1986a) are H-Y antigen positive (Simpson et al., 1987). The human Y chromosome has been subdivided into seven major deletion in-

\footnotetext{
${ }^{1}$ 'To whom correspondence should be addressed at the Department of Pathology SM-30, University of Washington, Seattle, WA 98195
}

tervals (Vergnaud et al., 1986). Because the overlapping deletions of the $46, \mathrm{XY}$ females cover most of the short arm of the $Y$ chromosome (intervals 1, 2, 3, and $4 \mathrm{~A}$ ), the $\mathrm{H}-\mathrm{Y}$ antigen gene is likely to be located on the proximal short arm or on the long arm of the $\mathrm{Y}$ chromosome (Simpson et al., 1987).

In mouse, the $\mathrm{H}-\mathrm{Y}$ antigen gene (Hya) is also distinct from the testis-determining gene (Tdy). Although both map to the short arm of the Y chromosome, Hya, but not Tdy, is deleted in Sxrb mice (McLaren et al, 1984). In XO Sxrb male mice lacking the H-Y antigen, spermatogenesis is blocked, leading Burgoyne et al. (1986) to suggest that the $\mathrm{H}-\mathrm{Y}$ antıgen gene or a gene closely linked to it plays a role in spermatogenesis. In humans, a fertility gene has been mapped to the long arm of the $Y$ chromosome (Tiepolo and Zuffardi, 1976). This fertility gene might or might not be identical to the $\mathrm{H}-\mathrm{Y}$ antigen gene.

In this paper, we report the sublocalization of a gene encoding or controlling the expression of the $H-Y$ transplantation antigen to a portion of interval 6 on the long arm of the human $\mathrm{Y}$ chromosome. We describe eight patients whose genetic alterations in the long arm of the Y chromosome allow us to refine the deletion map. Molecular analysis of the deletions in these eight cases results in the ordering of new DNA markers in this interval. The new DNA probes specific for interval 6 of the $Y$ chromosome may prove useful for the isolation of the $\mathrm{H}-\mathrm{Y}$ antigen gene or other genes in this interval.

\section{MATERIALS AND METHODS}

Case Reports and Cytogenetı Analysis

Case 1 (LGL 114) This case was previously reported (de la Chapelle et al, 1986, case 2, Andersson et al, 1988, case 3). Briefly, this patient had penoscrotal hypospadias Two small left testes appeared histologically normal at 5 months of age At age $8 \frac{1}{2}$ years his height was 


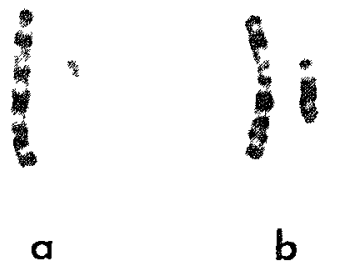

FIG. 1. Examples of the X and Y chromosomes staned by G banding from case 2 (a) and from his father (b)

in the 2 nd percentile Case 1 is a $45, \mathrm{X}$ male with $\mathrm{Y}$ chromosome mate rial, including the short arm and proximal long arm, translocated on the short arm of chromosome 14 in all lymphocytes and in a portion of fibroblasts, as described previously (Andersson et al 1988, case 3) The parents had normal karyotypes

Case 2 (SA 23) This patient was first evaluated at 1.3 years of age for a slipped left capital femoral epiphysis His height was within the 75-90th percentile and he was overweight Physical examination showed short fourth and fifth metacarpals, delayed sexual maturation, and small teeth with translucent enamel The degree of shortening of his metacarpals suggested a possible diagnosis of Albright's hereditary osteodystrophy, but levels of serum calcıum, phosphorus, parathyrovd hormone, and urine cyclıc AMP were withın normal limits Pubertal elevations in serum testosterone and gonadotropin were delayed in onset Testosterone level was $03 \mathrm{mg} / \mathrm{ml}$ (compared to the normal range of 30 to $90 \mathrm{mg} / \mathrm{ml}$ ) at 13 years, but normalized at 15 years of age (375 $\mathrm{mg} / \mathrm{ml}$ ) Luteınızing hormone (LH) and follicle stımulatıng hor mone (FSH) were $41 \mathrm{mIU} / \mathrm{ml}$ (normal is 84 to $250 \mathrm{mIU} / \mathrm{ml}$ ) and 48 $\mathrm{mIU} / \mathrm{ml}$ (normal is 34 to $197 \mathrm{mIU} / \mathrm{ml}$ ), respectively, at 13 years, with normalization at 15 years of age, $\mathrm{LH}$ was $77 \mathrm{mIU} / \mathrm{ml}$ (normal is 2 to 6 $\mathrm{mIU} / \mathrm{ml}$ ) and FSH was $118 \mathrm{mIU} / \mathrm{ml}$ (normal is 2 to $10 \mathrm{mIU} / \mathrm{ml}$ ) At 15 years, testicles measured 3 by $4 \mathrm{~cm}$ and pubertal development was Tanner Stage V He has had persistent bilateral gynecomastia with both glandular and fatty tissue present since he was first evaluated at age 13 years $H_{1 s}$ academic progress was hampered by emotional difhculties, with formal intelingence testing demonstrating average intell gence Chromosome analysis showed a small nonfiuorescent $Y$ chro mosome (Fig 1a) resulting from a deletion of the long arm or the formation of a ring chromosome with deletion of the bright fiuores cent $\mathrm{Q}$ band of the long arm Because of the very small size of the marker, we could not distinguish between a deletion and a ring The karyotype was described as $46, \mathrm{X}, \operatorname{del}(\mathrm{Y})(\mathrm{q} 11)$ or $46, \mathrm{X}, \mathrm{r}(\mathrm{Y})$ The $\mathrm{Y}$ chromosome was present in all 122 lymphocytes examıned, with one cell having three copies of the deleted Y chromosome, suggesting a tendency to nondisjunction The father's karyotype was normal (Fig 1b)

Case 3 (SA 1) This case was previously published (Disteche et al, 1986b) Briefly, the patient was evaluated following exploratory lapa rotomy for bilateral cryptorchidism at 17 months of age, when the small right testis was removed and the left testis was reimplanted in the scrotum Both testes showed immature semmiferous tubules No mullerian structures were seen The phallus was normal without hy pospadias or chordae The patient had been asphyxiated at birth and subsequently had microcephaly and developmental delay Case 3 is a 45 , X male with a translocation of part of the $\mathrm{Y}$ chromosome, including the short arm and proximal long arm on one chromosome 15

Case 4 (WHT 1373) This male patient was noted at birth to have microcephaly, micrognathia and a small maxilla, a high arched palate, a beaked nose with the septum extending below the nares, and broad thumbs $\mathrm{He}$ had an undescended left testıs (stıll undescended at 9 months) and a small right testis The inner canthal and outer canthal distances measured at approximately the 97th percentile and there was synophrys Case 4 has a $46, X$,del( $Y)(q 1122)$ karyotype in 20 cells examined His parents had normal karyotypes

Case 5 (WHT 1318) This male patient was diagnosed with hypo spadias and an undescended left gonad that was found to be a streak Exploratory laparotomy revealed no evidence of a uterine remnant or other gonadal structures A biopsy of the right testis showed appar ently normal histology Case 5 showed a $46, \mathrm{X}$, psudic(Y)(q11 2) karyo type

Case 6 (LGL 1846) This case was previously reported (Andersson et al, 1988, case 1) He is a phenotypically normal male Case 6 is, like case 3, a 45, X male with $\mathrm{Y}$ chromosome material, including the short arm and proximal long arm, translocated to the short arm of chromo some 15 This is a familial translocation found in four generations

Case 7 (SA 28) This patient was evaluated at $2 \frac{7}{12}$ years of age for mixed gonadal dysgenesis He had hypospadias and an undescended right gonad The patient was otherwise healthy Height was at the 10 th percentıle At the time of orchiopexy, at $2 \frac{4}{12}$ years, he was found to have a streak gonad on the ingt with a fallopian tube and a un cornous uterus The left gonad, which was descended into the scro tum, was presumed to be a normal testis, it was not biopsied and its adnexae were not evaluated FSH, LH, and testosterone levels were prepubertal Case 7 shows a karyotype of 46 ,X,psudic( $Y$ )(q11 23) in all 46 metaphase cells examined from a lymphocyte culture The $Y$ chromosome appeared as a pseudodicentric nonfluorescent $Y$ chromo some with two copies of the short arm and proximal long arm The father's chromosomes were not studied

Case 8 (SA 26) This case was previously reported as patient 1 in the report of Drummond Borg et al (1988) Briefly, he had penule hypospadias with a normal sized penıs, a bifid scrotum, and a right partrally descended testis and a left ingunal testis The patient was otherwise healthy Nerther vas deferens was seen at the time of or chopexy, when the patient was 5 years of age On biopsy, the right testis appeared immature, but normal for age Case 8 is mosalc 45, X/ 46,X,psudic(Y)(q11 23) with 5 of 100 cells being 45,X (Drummond Borg et al, 1988) The $\mathrm{Y}$ (hromosome is nonfluorescent and appears pseudodicentric with two copies of the short arm and proximal long arm The father's karyotype was normal 46,XY

\section{Southern Blot Hybridization}

DNA was prepared from perapheral blood lymphocytes or EpsteinBarr virus transformed lymphoblastord cell lines and then submitted to restriction digestion, electrophoresis, and Southern blot hybridiza tion by standard techniques (Sambrook et al, 1989) Hybridization and washing with all previously described DNA probes were per formed at high or reduced stringency as described by Cantrell et al (1989) and Disteche et al (1986b) Probe pMA5 5 ddentıfies the ame logenın gene and recognizes a polymorphic $Y$ specific band $(\simeq 15$ and $18 \mathrm{~kb}$ ) on TaqI digests (Lau et $a l, 1989$ ) The new interval 6 probes, pMC4, pMC110, pMC118, pMC147, and pJB1, were hybridized and washed at high stringency (Cantrell et al, 1989)

Probes pMC4, pMC110, pMC118, pMC147, and pMC50 were 1 so lated from a PERT (phenol enhanced reassociation technique) is brary (Cantrell et al 1989) and contain inserts of less than $100 \mathrm{bp}$ cloned in a pBR322 plasmid vector at the BamHI site The small in sert from $\mathrm{pMC50}$ was hybridized to a $\mathrm{Y}$ chromosome sorled library (from the Lawrence Livermore Laboratory) to isolate a Charon $21 \mathrm{~A}$ $\lambda$ phage clone that contaned homologous DNA sequences The $44 \mathrm{~kb}$ DNA insert from the Charon 21A $\lambda$ phage clone was then subcloned into plasmid pGEM $3 Z$ (Promega Corp) at the HindIII site to gener ate pJB1 Probe pMC4 recognizes two major DNA fragments ident fied as pMC4/A, at about $8 \mathrm{~kb}$, and $\mathrm{pMC} 4 / \mathrm{B}$, at $12 \mathrm{~kb}$, on an $E c o R I$ digest of human genomic DNA Probes pMC110, pMC118, and pMC147 recognize an $8 \mathrm{~kb}$ tragment, a $2 \mathrm{~kb}$ fragment (Fig 2), and a $3 \mathrm{~kb}$ fragment, respectively, on EcoRI digested human DNA Probe pJB1 recognizes 18 and $8 \mathrm{~kb}$ ragments on an EcoRI digest of geno mic DNA ( $\left.F_{1}{ }_{2} 2\right)$ Probe pJM77 is a genomic clone isolated directly from the $\mathrm{Y}$ chromosome sorted library The $3 \mathrm{~kb} \lambda$ phage insert was subcloned in plasmid pBSSK pJM77 recognizes a $20 \mathrm{~kb}$ band on a TaqI digest of human genomic DNA

Labelıng was performed by random primer hybriduzation as prevı ously described (Sambrook et al 1989), in most instances pMC4, pMC110, pMC118, and pMC147 were PCR amplufied from the plas mid with $\left[{ }^{32} \mathrm{P}\right] \mathrm{dCTP}$ present The primers used were $\mathrm{pBR} 322$ se quences flanking the BamHI cloning site, which had been destroyed 


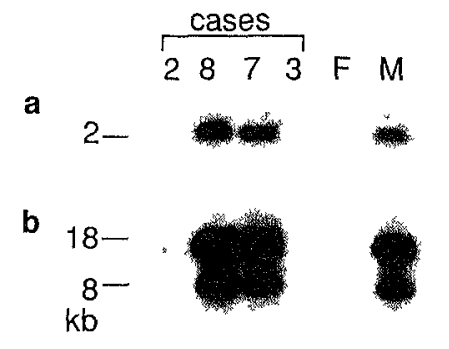

FIG. 2. Examples of Southern blot hybridizations of probes pMC118 (a) and pJB1 (b) to EcoRI-digested genomic DNA from cases $2,8,7$, and 3 , a normal female, and a normal male.

(primer A: 5'-GCGACCACACCCGTCCTGTG- $3^{\prime}$ and primer B: $5^{\prime}-$ ACGATGCGTCCGGCGTAGAG-3'). The reaction consisted of 10 $\mathrm{m} M$ Tris, $\mathrm{pH} 8.2,5 \mathrm{mM} \mathrm{NH} \mathrm{NH}_{4} \mathrm{Cl}, 1.5 \mathrm{mM} \mathrm{MgCl}_{2}$, and 50 or $100 \mathrm{mM}$ $\mathrm{KCl}$, approximately $1 \mathrm{pg}$ template DNA, $2 \mu M$ dATP, dTTP, and dGTP, $2 \mu M\left[{ }^{32} \mathrm{P}\right] \mathrm{dCTP}, 38 \mathrm{pmol}$ of each primer, and $2 \mathrm{U}$ Taq polymerase. The total volume was $15 \mu \mathrm{l}$. The mixture was denatured under oil for $5 \mathrm{~min}$ at $94^{\circ} \mathrm{C}$ and then cycled for $1 \mathrm{~min}$ at $94^{\circ} \mathrm{C}, 1 \mathrm{~min}$ at $65^{\circ} \mathrm{C}$, and $1 \mathrm{~min}$ at $72^{\circ} \mathrm{C}$ for a total of 25 cycles. The final extension totaled $6 \mathrm{~min}$ at $72^{\circ} \mathrm{C}$. Labeled DNA was purified through Sephadex G50 spin columns prior to blot hybridization.

\section{H-Y Antigen Typing}

Prior to $\mathrm{H}-\mathrm{Y}$ antıgen typing, HLA typing was performed to determine whether the patients were of A2 or B7 types, since the T-cell clones available for $\mathrm{H}-\mathrm{Y}$ typing were restricted by either HLA-A2 or HLA-B7. Standard HLA serotyping was performed at the tissue typing laboratory at the Royal Postgraduate Medical School (Hammersmith, London) by Mr. Nick Davey and by fuorescence-activated cell sorting (FACS) analysis at the Clinical Research Centre (Harrow, UK) using the HLA-A2-specific monoclonal antibody HB82 (BB7.2) and the HLA-B7 (crossreastive on B40) monoclonal antibody HB59 (MB40.2). For cases 7 and 8, FACS analysis only was used. Expression of HLA-A2 and HLA-B7 alloantigens identified by T cells was confirmed by cytotoxic T-cell lysis (CTL) experiments in which the patients' cells were also typed for H-Y (Simpson et al., 1987). EpsteinBarr virus-transformed lines from each of the patients were used as target cells in CTL assays, except for patent 3, for whom a fibroblast line was used. The cytotoxicity was measured in a ${ }^{51} \mathrm{Cr}$ release assay as described in Simpson et al (1987). Control normal male and female cell lines were examined with each experiment.

\section{RESULTS}

\section{DNA Analysis}

Case 1 was previously analyzed using a series of DNA probes as reported in Andersson et al. (1988). Reevaluation of this case with new DNA probes for the long arm of the $\mathrm{Y}$ chromosome confirms that this patient is deleted for intervals 5, 6 , and 7 . This patient has the largest deletion of the patients studied here, including a portion of interval 5 recognized by probes pJM77 and p12f (Table 1).

Case 2 has the next largest deletion but is positive for probe pJM77, indicating that the new locus recognized by pJM77 is proximal to the locus for p12f (Table 1; Fig. 2 , case 2). Evaluation of relative hybridization intensities in case 2 compared to those of normal males shows increased hybridization to $\mathrm{Y}$-specific bands that could be quantified relative to $\mathrm{X}$-specific bands for probes specific for intervals 1 (pDP1007 and pDP132) and 2
(pDP61) (Fig. 3, case 2), but not for probes specific for intervals $3(52 \mathrm{~d} / \mathrm{B}$ and $50 f 2 / \mathrm{A}, \mathrm{B})$ and 4 (pDP34 and pMA5-5). The patient, therefore, appears to have a deletion of intervals 6 and 7 and distal interval 5 , as well as a duplication of intervals 1 and 2 .

Case 3 was previously shown to be deleted for DNA sequences in intervals 6 and 7 of the $\mathrm{Y}$ chromosome (Disteche et al., 1986b). Reevaluation of this patient confirms these findings and allows us to order some of our new DNA probes (Table 1; Fig. 2, case 3). Due to the unavailability of the patient whose deletion allowed Vergnaud et al. (1986) to define the border of intervals 5 and 6 (Jean Weissenbach, personal communication), we arbitrarily assigned $12 f$ as defining the distal border of interval 5. Thus, purely for simplicity, we will consider all DNA probes located distal to p12f to be located in interval 6 or 7 .

Case 4 is deleted for interval 7 and has a partial deletion of interval 6 (Table 1). Case 5 is also deleted for interval 7 and shows the smallest deletion of interval 6 , including probes pJB1 and pMC4/A (Table 1).

Analysis of cases 6,7 , and 8 by Southern blot hybridizations (Table 1; Fig. 2, cases 7 and 8) shows that these patients contain DNA sequences recognized by all of the probes for interval 6. Absence of the highly fluorescent $Q$ band ( $\mathrm{Yq} 12)$ on their Y chromosomes and lack of hybridization to $\mathrm{pY} 3.4$, which recognizes one of the DNA repeats located in interval 7 of the $\mathrm{Y}$ chromosome, show them to be deleted for interval 7. Comparison of relative hybridization intensities in cases 7 and 8 shows increased hybridization to all $\mathrm{Y}$-specific bands that could be quantified relative to $\mathrm{X}$-specific bands for probes pDP1007, pDP132, pDP61, 52d/B, pDP34, and 50f 2/ A,B,E (Fig. 3, case 7). These increased intensities, which were also observed in case 5 , support the cytogenetic conclusion that these patients each contain a pseudodicentric $\mathrm{Y}$ chromosome, with duplication of most of the $\mathrm{Y}$ chromosome except for band q12.

\section{$H-Y$ Antigen Testing}

Cells from the patients were examined for expression of H-Y antigen by CTL assays as described in Simpson et al. (1987). These data are summarized in Table 2. The lymphoblastoid cell lines derived from cases 1, 2, and 4 were found to be $\mathrm{H}-\mathrm{Y}$ antigen negative. Case 3 tested $\mathrm{H}-\mathrm{Y}$ antigen ambiguous in three assays that could not be repeated due to the limited life span of the fibroblast cell line available on this patient. Fibroblasts are much less sensitive than lymphoblastoid lines as targets in CTL assays. Case 7 could not be tested because his HLA type is not $\mathrm{A} 2$ or $\mathrm{B} 7$. Cases 5,6 , and 8 were found to be positive. These results indicate that a gene encoding or controlling the expression of the $\mathrm{H}-\mathrm{Y}$ antigen is located in a portion of interval 6 containing loci for probes p50f $2 / \mathrm{E}$, pDP105/B, pMC4/B, and pMC118 (Tables 1 and 2). This gene appears to be proximal to loci for probes pJB1 and $\mathrm{pMC} 4 / \mathrm{A}$. 
TABLE 1

Identification of Y-Specific DNA Fragments in Eight Patients

\begin{tabular}{|c|c|c|c|c|c|c|c|c|c|c|c|}
\hline \multirow[b]{2}{*}{ DNA Probe } & \multirow[b]{2}{*}{ Locus } & \multirow{2}{*}{$\begin{array}{l}\text { Deletion } \\
\text { interval }\end{array}$} & & \multicolumn{8}{|c|}{ Case } \\
\hline & & & & 1 & 2 & 3 & 4 & 5 & 6 & 7 & 8 \\
\hline pDP1007 & $Z F Y$ & 1 & & $f^{a}$ & + & $t$ & + & + & + & + & + \\
\hline pDP132 & DXYS23Y & 1 & & + & + & + & + & + & $t$ & + & ND \\
\hline pDP61 & DXYS8Y & 2 & & + & + & + & + & + & + & + & + \\
\hline pMC23 & DYS142 & 3 & & ND & + & + & $\mathrm{ND}$ & $\mathrm{ND}$ & ND & + & + \\
\hline $\mathrm{p} 52 \mathrm{~d} / \mathrm{B}$ & DYF 27 & 3 & $p^{c}$ & + & + & $\mathrm{ND}$ & + & + & ND & + & $\mathrm{ND}$ \\
\hline pDP105/A & DYZ4 & 3 & & + & + & + & + & + & + & + & + \\
\hline p 50 f $2 / A, B$ & DYS7 & 3 & & + & + & + & + & 4 & + & + & + \\
\hline pDP34 & DXYS1Y & $4 \mathrm{~A}$ & & + & 1 & + & + & + & + & + & ND \\
\hline pMA5-5 & AMGI & $4 \mathrm{~A}$ & & ND & + & + & + & + & + & ND & $\mathrm{ND}$ \\
\hline pDP97 & DYZ3 & $4 \mathrm{~B}$ & $\operatorname{cen}^{c}$ & + & + & + & + & + & + & + & + \\
\hline pJM77 & & 5 & & - & + & + & + & + & + & + & + \\
\hline $\mathrm{p} 12 f$ & DYS11 & 5 & & - & - & t & + & + & + & + & + \\
\hline pMC110 & DYS144 & 6 & & - & - & - & + & + & + & + & + \\
\hline pMC147 & DYS146 & 6 & & - & - & - & -1 & + & $t$ & + & + \\
\hline $\mathrm{p} 50 / 2 / \mathrm{E}$ & DYS7 & 6 & & - & - & - & - & + & + & + & + \\
\hline $\mathrm{pDP} 105 / \mathrm{B}$ & DYZ4 & 6 & $q^{c}$ & - & - & - & - & + & + & + & + \\
\hline $\mathrm{pMC} 4 / \mathrm{B}$ & DYS143 & 6 & & - & - & - & - & + & + & + & + \\
\hline $\mathrm{pMC} 118$ & DYS145 & 6 & · & - & - & - & - & + & + & + & + \\
\hline p.JB1 & DYS147 & 6 & & - & - & - & - & - & + & $t$ & + \\
\hline$p M C 4 / A$ & DYS143 & 6 & & - & - & - & - & - & + & + & + \\
\hline pY3.4 & DYZ1 & 7 & & - & - & - & - & - & - & - & - \\
\hline HY typing ${ }^{b}$ & $H Y$ & 6 & & - & - & $?$ & - & + & + & ND & + \\
\hline
\end{tabular}

${ }^{a}$ DNA probes were used to test individuals for the presence $(+)$ or absence $(-)$ of the indicated Y-specific restriction fragments. ND, not done.

${ }^{b}$ See Table 2 for details of H-Y antigen testing.

${ }^{c}$ p, short arm; cen, centromere; $q$, long arm.

\section{DISCUSSION}

Our results indicate that a gene encoding or controlling the expression of the $\mathrm{H}-\mathrm{Y}$ transplantation antigen is located in a portion of interval 6 of the $\mathrm{Y}$ chromosome containing probes p50f 2/E, pDP105/B, pMC4/B, and pMC118 and defined by the breakpoints in cases 4 and 5 . These data restrict the location of the gene to a proximal portion of interval 6 .

The deletion map that we have constructed using previously isolated DNA markers and a series of new $\mathrm{Y}$ chromosome-specific DNA probes assumes that the chromosomal rearrangements of the patients result in simple breaks in the long arm of the $\mathrm{Y}$ chromosome and that there are no position effects in these rearrange-

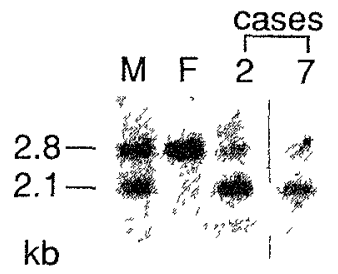

FIG. 3. Example of a Southern blot hybridization of probe pDP61 to TaqI-digested genomic DNA from a normal male, a normal temale, case 2 , and case 7 . The 2.8 - and $2.1-\mathrm{kb}$ bands represent the X-linked and Y-linked loci of DXYS8, respectively. The $2.1-\mathrm{kb}$ band is increased relative to the $2.8 \mathrm{~kb}$ band in cases 2 and 7 , whose rearranged $Y$ chromosomes contain two copies of region 2 of the $Y$ chromosome. ments. We cannot exclude the possibility that the chromosome breaks are more complex. By cytogenetic analysis, three cases (cases $1,3,6$ ) show a Y; autosome translocation that results in the presence of a portion of the long arm of the $\mathrm{Y}$ chromosome in the patients. Two cases (cases 2 and 4 ) show a terminal deletion of the long

\section{TABLE 2}

H-Y Antigen Testing

\begin{tabular}{|c|c|c|c|c|c|c|c|}
\hline \multirow[b]{2}{*}{ Case } & \multicolumn{2}{|c|}{ HLA serotype } & \multicolumn{4}{|c|}{$\begin{array}{l}\% \text { lysis with cytotoxic }{ }^{r} \Gamma \text { cells } \\
\text { specific for }\end{array}$} & \multirow[b]{2}{*}{ H-Y type } \\
\hline & $\mathrm{A}$ & B & $\mathrm{A} 2$ & $\mathrm{~A} 2 / \mathrm{H}-\mathrm{Y}$ & $B 7$ & $\mathrm{~B} 7 / \mathrm{H}-\mathrm{Y}$ & \\
\hline 1 & $\underline{2}^{a}$ & 27 & $58^{b}$ & 3 & $\mathrm{ND}^{r}$ & ND & - \\
\hline 2 & $\overline{3}, 9$ & 7,12 & $\overline{N D}$ & ND & 70 & 0 & - \\
\hline 3 & 2 & $\mathrm{ND}$ & $15^{d}$ & $7^{d}$ & $\overline{\mathrm{ND}}$ & $\mathrm{ND}$ & $?^{d}$ \\
\hline 4 & $\overline{2}, 9$ & 35,40 & 21 & 1 & ND & $\mathrm{ND}$ & - \\
\hline 5 & 10,19 & $\underline{7}$ & $\mathrm{ND}$ & ND & 30 & $\underline{65}$ & t \\
\hline 6 & 3 & $\overline{7}$ & ND & $\mathrm{ND}$ & $\overline{63}$ & $\overline{84}$ & + \\
\hline 7 & not 2 & not 7 & ND & ND & $\overline{\mathrm{ND}}$ & $\overline{N D}$ & ND \\
\hline 8 & 2 & $\mathrm{ND}$ & 57 & $\underline{67}$ & $\mathrm{ND}$ & ND & t \\
\hline
\end{tabular}

a 'The identity of the HIA molecule used as a restriction element for the detection of $\mathrm{H}$-Y antigen in the CTL assays is underlined in the HLA serotyping columns.

${ }^{b}$ Figures underlined in the CTL test columns are those showing significant levels of titrating lysis.

${ }^{\circ} \mathrm{ND}$, not done.

${ }^{d}$ Insensitive target, ambiguous results (in each of the three experiments performed with these cells). 
arm. Three cases (cases 5, 7, and 8) show a pseudodicentric Y chromosome with deletion of the distal long arm and duplication of the short arm and proximal long arm. In one additional case (case 2), it appears that the chromosome rearrangement is complex, involving both duplication and deletion of $\mathrm{Y}$-chromosome material. The abnormal $\mathrm{Y}$ chromosome of case 2 may be a ring chromosome or a short metacentric chromosome derived from an intermediate dicentric $\mathrm{Y}$ chromosome. It has recently been shown that some ring chromosomes 21 may derive from an intermediate dicentric chromosome 21 in a similar fashion (Wong et al, 1989; McGınnuss et al, 1992). Further analysis of the breakpoints and the use of pseudoautosomal DNA probes may help to define better the abnormal Y chromosome of case 2 .

The majority of patients in this study had genital abnormalities. Four patients had hypospadias (case 1, 5, 7, and 8). Undescended testes were found in cases $3,4,5,7$, and 8. Case 2, who has a large deletion, shows few anomalies, including delayed puberty, low testosterone levels, and gynecomastıa, but apparently normal genitalıa. Case 2 also had short fourth and fifth metacarpals, an anomaly previously seen in a patient with a long-arm deletion of the $\mathrm{Y}$ chromosome (Fitch et al, 1985) and often reported in cases of Turner syndrome (Hall et al, 1982). Where available, testicular biopsies of the patients showed apparently normal histology, although the testes were usually small, except in case 6 who is a normal fertıle male. A gene related to fertility has been assigned to the long arm of the Y chromosome on the basis of the observation of an excess number of individuals with deletion of the long arm of the $\mathrm{Y}$ chromosome among infertile males (Tiepolo and Zuffardi, 1976). Additıonal reports support this association between deletion of Yq and azoospermia (Munke et al, 1985; Fitch et al, 1985). On the basis of the present case 6 and other patients, Andersson et al (1988) assigned the fertility factor to interval 6 of the $\mathrm{Y}$ chromosome. In our cases (except case 6 as noted above), fertility and sperm production could not be assessed because of the age of the patients. In addition, the aberrations in testicular development of cases 5,7 , and 8 may be secondary either to their Y-chromosome abnormality or to known (in case 8) or possible mosaicism for $45, \mathrm{X}$ cell line.

The combination of cytogenetic analysis and Southern blot hybridization in the eight patients described has allowed us to assign six new DNA probes to interval 6 of the $\mathrm{Y}$ chromosome and to order them at least in part. These probes should be useful for further characterization of the Y chromosome and of specific deletions assocrated with specific phenotypes. Several other deletion maps of the long a:m of the $\mathrm{Y}$ chromosome have been reported (Vergnaud et al, 1986; Muller et al, 1986; Affara et al, 1986; Oosthuizen et al, 1990; Koteckı et al, 1991; Nakahorı et al , 1991; Bardon1 et al , 1991), providing tools to isolate genes in this chromosomal region. The present analysis provides evidence for a more precise location of the $\mathrm{H}-\mathrm{Y}$ antigen gene to a portion of interval 6 , which will be useful for its isolation.

\section{ACKNOWLEDGMENTS}

This work was supported by grants from the March of Dimes Birth Defects Foundation, the American Cancer Society, the National Inst1tutes of Health, the Harvard-MIT Division of Health Sciences and Technology Johnson and Johnson Research Fund, the Academy of Finland, the Sigrid Juselius Foundation, and the Folkhalsan Institute of Genetics We thank Jean Weissenbach (Instıtut Pasteur, Parıs), Y F Lau (University of Calıfornıa, San Francisco, CA), and Malcolm L Snead (University of Southern Caluforma, Los Angeles, CA) for DNA probes We thank Drs Jonathan Park and Doris Wurster Hill for the initial cytogenetic study of case 2, Drs Urvashı Surtı and San dra Marchese for clinical and cytogenetic studies of case 4, and Dr John Vigorita for providing clinical and cytogenetıc information con cerning case 5 We thank Cynthı Friedman, Steve Forbes, and Doug Chapman for technical assistance and Janice Garr for typing the manuscript

Note added in proof Recent Y-DNA testing of patient CHM018 (DNA kundly provided by Jean Weissenbach), whose Y chromosomal breakpoint historically defined the boundary between intervals 5 and 6 (Vergnaud et al, 1986), suggests that the boundary is located more distally on Yq than we had assumed Such a "recalibration" of dele tion intervals 5 and 6 would not affect the ordering of breakpoints, DNA locl, and $\mathrm{H} \mathrm{Y}$ antigen reported here and will be discussed in a subsequent publication

\section{REFERENCES}

Affara, N A, Florentin, L, Morrison, N, Kwok, K, Mitchell, M, Cook, A, Jamieson, D, Glasgow, L, Meredith, L, Boyd, E, and Ferguson Smith, M A (1986) Regional assignment of Y-linked DNA probes by deletion mapping and their homology with $\mathrm{X}$ chro mosome and autosomal sequences Nuclelc Acıds Res 14: 53535373

Andersson, M, Page, D C, Pettay, D, Subrt, I, Turleau, C, de Grouchy, J, and de la Chapelle, A (1988) Y, autosome transloca tions and mosaicism in the aetrology of 45, $\mathrm{X}$ maleness Assignment of fertility factor to distal Yq11 Hum Genet 79:2-7

Bardonı, B , Zuffardı, O, Guıolı, S, Ballabı, A , Sımı, P, Cavallı, P, Grimoldı, M G, Fraccaro, M, and Camerıno, G (1991) A deletion map of the human Yq11 region Implications for the evolution of the $\mathrm{Y}$ chromosome and tentative mapping of a locus involved in sper matogenesis Genomics 11: 443-451

Butgoyne, P S, Levy, E R , and McLaren, A (1986) Spermatogenic falure in male mice lacking $\mathrm{H}-\mathrm{Y}$ antigen Nature 320: 170-172

Cantrell, M A, Bicknell, J N, Pagon, $R$ A, Page, D C, Saal, H, Zinn, A B, and Disteche, C M (1989) Molecular analysıs of $46, \mathrm{XY}$ females and regional assignment of a new $\mathrm{Y}$ chromosome specific probe Hum Genet 83: 88-92

de la Chapelle, A, Page, D C , Brown, L , Kaski, U, Parvinen, T , and Tippett, P A (1986) The origin of 45,X males Am J Hum Genet 36: $330-340$

Disteche, C M, Casanova, M, Saal, H, Friedman, C, Sybert, V, Graham, J Thulıne, H , Page, D C , and Fellous, M (1986a) Small deletions of the short arm of the Y chromosome in $46, \mathrm{XY}$ females Proc Natl Acad Scl USA 83: 7841-7844

Disteche, C M , Brown, L, Saal, H, Friedman, C, Thulıne, H C, Hoar, D I, Pagon, R A, and Page, D C (1986b) Molecular detec tion of a translocation $(\mathrm{Y}, 15)$ in a 45,X male Hum Genet 74:372377

Drummond Borg, M, Pagon, R A, Bradley, C M , Nordlund, J and Salk, D (1988) Nonfluorescent dicentric Y m males with hypo spadias $J$ Pediatr 113: 469-473

Elchwald, E J, and Silmser, C R (1955) Untıtled Transplantation Bull 2: 148

Fitch, N, Richer, C L, Pinsky, L, and Kahn, A (1985) Deletion of the long arm of the $\mathrm{Y}$ chromosome and review of $\mathrm{Y}$ chromosome abnormalities Am J Med Genet 20: 31-42 
Gordon, R, Simpson, E, and Samelson, L (1975) In vitro cell me drated immune responses to the male specific $(\mathrm{H} \mathrm{Y})$ antigen in mice of Exp Med 142: 1108-1120

Goulmy, E, Termitelen, A, Bradley, B A, and Van Rood, J J (1977) $\mathrm{Y}$ antigen killing by $\mathrm{T}$ cells of women is restricted by HLA Nature 226: 544-545

Guellaen, G, Casanova, M, Bishop, C, Geldwerth, D, Andre, G Fellous, M and Weissenbach, $J$ (1984) Human XX males with $Y$ single copy DNA fragments Nature 307: 172-173

Hall, J G, Sybert, V P, Willamson, R A, Fisher, N N, and Reid $S \mathrm{D}$ (1982) Turner syndrome Western d Med 137: 32-44

Koteckı, M, Jaruzelska, J , Skowronska, M, and Fichna, P (1991) Deletion mapping of interval 6 of the human Y chromosome Hum Genet 87: 234-236

Lau, E C , Mohandas, T K, Shapıro, L J , Slavkın, H C , and Snead, M L (1989) Human and mouse amelogenm gene loc1 are on the sex chromosomes Genomics 4: $162-168$

McGinnıss, M J, Kazazıan, H H, Jr, Stetten, G, Petersen, M B Boman, H, Engel, E, Greenberg, F, Hertz, J M, Johnson, A, Laca, Z, Mikkelsen, M, Patıl, S R, Schınrel, A A, Tranebjaerg, L, and Antonarakıs, S E (1992) Mechanisms of ring chromosome formation in 11 cases of human ring chromosome $21 \mathrm{Am} J \mathrm{Hum}$ Genet 50: 15-28

McLaren, A, Simpson, E Tomonar, K, Chandler, P, and Hogg, H (1984) Male sexual differentiation in mice lacking $H \mathrm{Y}$ antigen Nature 312: 552-555

Muller, U, Donlon, T, Schmid, M, Fitch, N, Richer, C L, Lalande $M$, and Latt, S A (1986) Deletion mapping of the testis determin ing locus with DNA probes in $46, \mathrm{XX}$ males and in $46, \mathrm{XY}$ and 46,X,dic(Y) females Nucleve Acıds Res 14:6489-6505

Munke, M, de Martınville, B, Lieber, E, and Francke, U (1985) Mrnute chromosomes replacing the $\mathrm{Y}$ chromosome carry $\mathrm{Y}$ specific sequences by restriction fragment analysis and in situ hybridiza tion Am J Med Genet 22: 361-374

Nakahor, Y, Takenaka, O, and Nakagome, Y (1991) A human X Y homologous region encodes "amelogenın" Genomics 9: 264-269

Oosthuizen, C J J, Herbert, J S, Vermaak, L K, Brusnicky, J , Fricke, J , du Plessis, L, and Retıef, A E (1990) Deletıon mapping of 39 random isolated Y chromosome DNA fragments Hum Genet 85: 205-210

Pohischmidt, M, Rappold, G, Krause, M, Ahlert, D, Hosenfeld, D , Weissenbach, J, and Gal, A (1991) Ring Y chromosome Molecu lar characterization by DNA probes Cytogenet Cell Genet 56: 6568

Sambrook, J, Fritsch, E F, and Manıatıs, T (1989) "Molecular Cloning A Laboratory Manual," second ed Cold Spring Harbor Laboratory, Cold Spring Harbor, NY

Simpson, E (1982) The role of $\mathrm{H}$ Y as a minor transplantation ant gen Immunol Today 3: 97-106

Simpson, E, Chandler, P, Goulmy, E, Disteche, C M, Ferguson Smith, M A, and Page, D C (1987) Separation of the genetic loc for the $\mathrm{H} \mathrm{Y}$ antigen and for testis determination on human $\mathrm{Y}$ chro mosome Nature 326: 876878

Tiepolo, L, and Zuffardı, O (1976) Localıatıon of factors controlling spermatogenesis in the nonfluorescent portion of the human $Y$ chromosome long arm Hum Genet 34: 119-124

Vergnaud, G, Page, D C, Simmler, M C, Brown, L, Rouyer, F Noel, B, Botstein, D, de la Chapelle, A, and Weissenbach, J (1986) A deletion map of the human Y chromosome based on DNA hybridization Am J Hum Genet 38: 109-124

Wong, C, Kazazian, H H, Jr, Stetten, G, Earnshaw, W C, Van Keuren, M L, and Antondrkakıs, S E (1989) Molecular mecha nism in the formation of a human ring chromosome 21 Proc Nat Acad Scl USA 86: 1914-1918 